\title{
Difable Literacy: Analysis of Difable Representation in Indonesian Media
}

\author{
Hanna Nurhaqiqi \\ \{hannanurhaqiqi@yahoo.com\} \\ Faculty of Social and Political Science, Universitas Gadjah Mada, Indonesia
}

\begin{abstract}
Media play a role in creating the construction. Representation in the media which displayed continuously can be defined as a truth by the public. In this context, the media has a responsibility to the public in presenting constructions that are in accordance with reality without generating stigma and stereotypes. Otherwise, the media often display it continuously. Both in the online news and soap opera (sinetron) on television. While presenting about disability issues as empathic and submarginall objects rather than as equal public. Regarding the regulation of disability, the Difable entitled to be free from stigma. There should be an equal condition for every Difable person that has to be understood by non-Difable people. They (non-Difable) have the right to know the real condition without media exposure which stigmatizes about the disability issues. Studies on the representation of disabilities in the media are limited and need to be explored further on the disability as part of the public media. Using representational analysis and inclusivity in the media to examine the dynamics of Difable representation in Indonesian media
\end{abstract}

Keywords: Representation, Difable Literacy, Media, Inclusive

\section{Introduction}

The media has a role in creating construction to audiences. Media also has a role in education and entertainment to the audience in a proper way. Then the content and the production process is very important in conducting media activities. With regard to construction, the media is able to describe an image as well as a definition of an event. When the media present something as a truth, then the tendency of audiences will believe the truth. Media has the confidence of perception to the audience.

Content meaning which presented in the media has accepted by audiences. It called media representation. According to Hall [1] reproduction is the production of meaning through language and constructionists argue that we use signs, organized into languages of different kinds, to communicate with others. This reveals that the representation process, there is a powerful meaning implied behind the visible symbol of communication. Just as in the media representation, what is not the media is explicitly expressed but has a strong meaning and captured by the audience as a definitive or truth.

In general, the media have a different view of the disability issue. Different can vary both negative and positive. Negative views, for example, tend to look discriminately against events or news about Difable people or disability issues. Also with a positive outlook on the issue of disability, by providing an empathy that exceeds the limit of reasonableness. Where the sense of empathy is shown instead to provide a gap or distance between those who norm with the abnormal or Difable. The media's view of this disability issue is on two different sides but 
provides discrimination and an exclusive view to the Difable. The media's ability to see this disability issue provides a strong representation of the media to audiences about the definition of disability issues or Difable persons as sub-marginal determinants or object of pity.

Media trends that give negative or positive meanings about disability issues in the media create a stigma or stereotype that is peculiar to the public. The stigma and stereotype will become generally accepted definitions and meanings. According to Bendukurthi and Raman [2] the representation of disability is important in looking at two things: first, in shaping the idea and attitudes toward the Difable and second, creating or building the desire to participate in disabilities in the wider social circle. The two impacts of representation have a fundamental difference. First, the media representation of the disability issue makes the Difable as the reverse object. Second, representations formed making the public view the Difable as an active subject so that the Difable can be involved inclusively without feeling different/distinguish physically or mentally.

The stigma attached to the Difable by media construction is a deviation of the media's basic nature of imbalance of neutrality. According to the Act on Disability No. 8 of 2016 article 7 states that "the free right of stigma for Persons with Disabilities includes the right to be free from harassment, humiliation and negative labeling related to its disability condition". This is to emphasize that stigma labels are not permitted either in any medium for human rights violations. Therefore, if the media provides a disability representation attached to stigma or stereotype then media break the regulations which are legalized in Indonesia.

Disability is generally defined as a physical, sensory or cognitive limitation, or otherwise, the definition considered by the 'normal' people (ableist society) not exist in itself within this sphere of complexity[2]. In the Convention on the Rights of Persons with Disabilities agreed upon on 13 December 2006 by the United Nations General Assembly (UN) and Indonesia including in its agreement to adopt a "Universal Design" namely "the design of products, environments, programs, and services to be usable by all people, to the greatest extent possible, without the need for adaptation or specialized design. Its shall not exclude assistive devices for particular groups of persons with disabilities where this is needed". A universal design involving anyone can participate in meeting the needs of public or civil society. When disabilities and disability issues are always objects and sub-marginal, this context is outside the universal design.

Equality and justice to gain the same perception as the public is a fundamental right that all elements of societies provide. In this case, the Difable are entitled to be released from the stigma inherent in media. Also, the non-Difable public is also entitled to a neutral definition of the disability so that it does not become an extension of the construction of the media in conducting objectification to the Difable. Media in Indonesia that actually make the stigma as a content product that sells and attracts audiences make it disregard to improve the definition of reality. This condition is feasible considering the existence of media that has a central role in the public as a transmitter of information and truth. In this paper at the beginning describes the formulation of the problem of how the dynamics of representation Difable in Indonesian media. Then theoretical studies with theories of representation and inclusivity. To understand the process of representation in the media and communication process code. As well as the concept of inclusiveness about how media should behave and conduct its production process. The last discussion, about the television soap operas and news coverage on the online news portal in presenting the issue of disability. 


\section{Research Question}

The existence of the media has a central role in the construction of the public on the issue of disability. Because this representation involves the rights of persons with disabilities as a part of the public free from stigma. The media should not be agents or perpetrators who perpetuate the stigmatization of disability issues. In this era of press freedom now, the ideal media qualification is absolutely sided with the public. When the media is in the comfort zone and does not self-evaluate in the production of information and content then the media has violated the trust owned by the public.

In this paper, we try to analyze how the representation of disability issues in Indonesia. Describe the stigma and stereotypes that are generally present in information products and content by the media especially in Indonesia. As in television, where the intensity of exposure to television is very high to the audience. Inside there are impressions of information such as news and entertainment shows in soap operas, movies, reality shows, and many others.

\section{Theoretical Studies}

\subsection{The Power of Construction: Representation in media}

The representation of minorities in the media tends to get discriminated and actually reinforces the stigma in society. According to Hall, this situation is getting worse as in the news blacks and whites in America [1]. Correspondents proclaim crime using different justifications if the criminals are white and vice versa. This has become a bad tradition for the media to improve the stigma that should be escaped and inclusive, giving equal treatment or perception to every element of society. Objectification has frequent occurrence in media activities, even sticking to the news. It is that makes the theory of representation as an awareness of the existence of objectification, stigmatization or construction by communicators or the media.

There are three representational approaches by Hall[1]. First, a reflective approach in which the meaning humans do with ideas, media objects, and experiences that are present in people's lives. Second, the intentional approach, through the speech of both spoken and written language. Then the constructionist approach, this approach used in media representation where communicators make selections, selections and determine the meaning in messages or other information products. These three approaches can be used in understanding the media, but the media's ability to construct a definition and meaning becomes a closer approach to understanding media representation.

John Fiske[3] classifies the process of representation through three stages. First, the reality in the television selection of writing language, which symbol will be used. Second, the representation with the use of existing written languages then transmitted into the representational code and an object resulting in narration, logic, and dialogue. Finally, the ideology which the process of representation has taken place deeply and strongly understood by the audience to become an ideology or understanding. Writing language organized into a logical code such as liberalism, socialism, materialism and other isms. In essence, representation is a dynamic process and continues to grow along with changing code or increasing criticism and ability to process information of audiences.

In the representation of Difable tendency is a stereotype or stigma. As in films, for example, it forms a stereotypical construction to the Difable while the stereotype does not represent the overall disability condition. Black and Pretes[4] categorize widespread films in the world into seven broad categories (a) pitiable and pathetic (b) supercrip (c) sinister, evil and criminal (d) better-off dead (e) maladjusted ) a burden ( $\mathrm{g}$ ) unable to live a successful life. Each of the 
categories in the films tends to be negative and describes the sad, troubling and always unreliable conditions of disability. Even on "supercrip" term, where Difable character who have the spirit and high motivation to fight for life. Supercrip figures are portrayed as highly difable and able to compete beyond the "normal" human capabilities. This unsolicited stereotype gives the perception that those with disabilities should have an above-average life spirit and are required to have a harder portion of the struggle while not all "normal" humans are required as such.

Stereotypes that occur not only in films but also on online media such as news portals. The use of defective words limps, limitations, inadequacies, and the concept of excessive empathy in perceiving a condition of disability into news and other information. Unlike the term Difable derived from English abbreviations that Differently of able people, people with different abilities are not limited. Difable is a more inclusive term, neutral term and does not discriminate against a particular group such as supercrip, handicap, a burden, etc. In the research of Bendukurthi and Raman[2] conducting research on two leading news portals in India, The Hindu, and Eenadu, shows data is commonly used discriminatory terms in describing the disability. Such as Guddi-Blind, Kunti-Cripple, Cheviti-Deaf, Lopam-Defective, Durbaluru/Avitavallu-Disabled, Vaikalyam-Handicapped, Nissativa-Impaired, and ManasikaMental. The Media has power over Language selection in the production of information. This condition is actually supported by the lack of resources of journalists or producers who are not including the Difable. Seeing the Difable people as an object rather than a subject.

\subsection{Inclusivity and Accessibility in the media}

Media has a role in creating representations. Whether we realize it or not, the public's right involved in its meaning. There is a counterweight in overcoming a partial or discriminatory representation. An attitude that means that every individual is entitled to the same public rights, is entitled to the same perception and not attached to stigma, this attitude is called "inclusive". According to Joni Yulianto, Director of SIGAB (Sasana Integration and Advocacy DifableNonGovermental Organization) revealed that the concept of inclusive is in three domains. The first sphere of understanding and treatment. The assumption of the non-Difable (normal) people who see the Difable as a negative object, should not be, horrible or otherwise pitied, objects to be helped and need compassion. Inclusive in this realm of understanding to the public on the Difable has the same right to live independently and free from stigma. Assistance and fulfillment of the tools of need also use ethical limits as an interaction between humans in general who have human rights in fulfillment of public rights. Second, the policy domain where the protection of the rights and obligations attached to the Difable is legally recognized. Such as the Protection Act on the rights of disability no 4 of 1997 and the Disability Act No. 8 of 2016. This idea is also in line with the democratic media value in Indonesia[5]. The recognition of legitimacy is important in increasing inclusiveness in the public sphere in Indonesia. Only if a country has embedded inclusivism that releases stigma and stereotypes on the Difable than the problem goes to be easier. Public facilities accommodate the needs of the Difable to meet the needs independently[6]. However, in Indonesia inclusivism is at a stage of struggle and reinforced through the existing legal constitution. Third, the realm of accommodation. This includes accessibility in public space. For example in media, watching television is accessible to the deaf, in a discussion with a deaf activist from SIGAB, they claim to be more comfortable term with deaf/tuli when compared with hearing impaired/tuna rungu. Also, access online media on smartphones by Blind Difable. The presence of pop-up ads that suddenly appear to fill the page and provide a small close " $x$ " image with an indeterminate location, it is difficult for Blind Difable to click the " $\mathrm{x}$ " button. Not only the public is entitled to a fair definition of the 
disability issue but also the Difable with access to the same information and perception as the public.

\section{Discussion}

\subsection{Difable Representation}

\subsubsection{Indonesia Soap Opera on Television}

Television program broadcasting in Indonesia has a tendency to raise the stigma of the Difable. Soap operas or FTV (Film Television) that characterizes the Difable as a dominant subject but weak, belittled, lacking in strength, or having a positive spirit in an environment of disdain. The stereotypes attached to the Difable character in the soap opera give a negative perception to the public seeing the Difable in the society. This media behavior is a form of violation of the rights to people with disabilities and the public right to obtain correct information and images of persons with disabilities.

Soap opera "Ayah, Mengapa Aku Berbeda" on RCTI station strengthens the character of a deaf named Angel. She portrayed as a central figure being crushed by a handsome man and contested many high school female students at her age. In this soap operas clearly depicted about the condition of Angel who struggled to be patient if laughed at her friends because of the ability to hear is different from others, the scene of physical abuse becomes so natural and often aired in this soap opera. Normalization of this harassment is a form of violation of basic ethics in upholding Human Rights.

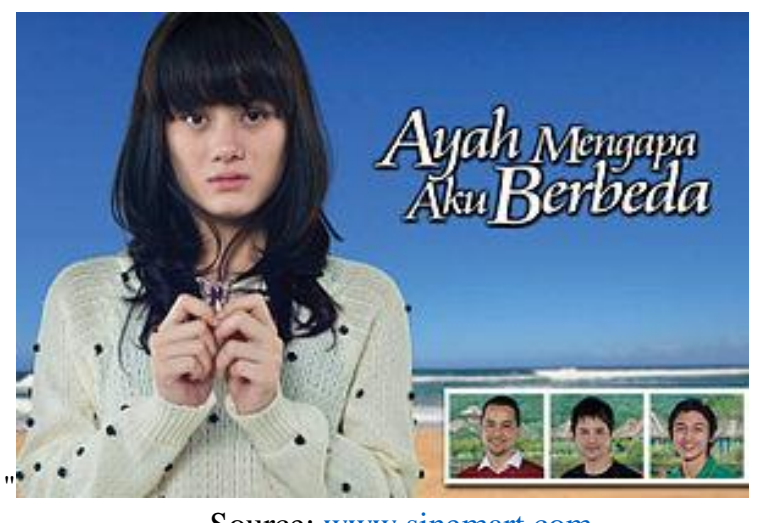

Source: $\underline{w w w . s i n e m a r t . c o m}$

Fig. 1. Soap Opera with Figures Difable "Ayah, Mengapa Aku Berbeda"

Soap opera representation in Hall prediction[1] as media tendency to worsen the object. In that sense, the object of interest in the stigma then the stigma will be preserved for the sake of the sustainability of the media. This condition is contrary to the concept of inclusiveness, in which the stigma of harassment is detrimental to the Deaf Difable that in real life is not as bad and simultaneously as lucky Angel figures. This soap opera also received a warning of violations by the KPI [7] with the statement "verbal abuse such as harassing the poor, insulting children with special needs (physical disabilities), insulting parents and Teachers, inappropriate use of words such as wretched children, hair iron, body brick". Soap Opera producers in "Ayah, Mengapa Aku Berbeda" ignore the inclusive principle in presenting public broadcast impressions. 
Unfortunately, this soap opera is not the only view that attaches stereotypes to Difable figures. Like the Indosiar station, in the "Sinema Pagi" and "Sinema Sore" productions of FTV also uses the term "defect" as its FTV title. Namely "Gara-gara suami anakku cacat", "Anak cacat pembawa berkah" and other FTV titles. As well as Trans TV show reality program with "Survivor, Let's Go, Let's Get Lost". The program describes the figure with physical limitations and made into a drama story from the side of their love life and work. The program released the stigma attached to the Difable.

\subsubsection{Online News Portal: Tempo.co and Kompas.com}

Stigma that appears on television shows also occur on online media news portal. Selection of words and viewpoint seeing the issue of disability is effecting in shaping construction Difable to the public. On the other hand, Indonesia has a dominant media concentration. Where media ownership of various platforms is mostly owned by 12 media holdings[8]. The media concentration implies the homogeneity of the content in the production of impressions and printed information. The same viewpoint in various media allows the same representation of disability issues by using stigma.

With two major news media in Indonesia, on their online news page Tempo.co and Kompas.com. To look for the words "Orang Cacat-Impaired" and "Difabel" (term Difable commonly used with Difabel among Indonesian) on the search engines of each news page. It was found that the tendency of the two news media mostly uses the term "Orang Cacat" compared to "Difable". Logically, the retrieval of Difable terms that the media knows should allow usage of the entire context. However, there is an imbalance in the use of both terms. News media, in this case, Tempo.co and Kompas.com play a role in representing the news about the issue of disability. A high degree of legibility to the public has the effect of releasing stigma or actually perpetuating it. Unfortunately, the use of the term "Orang cacat" is more widely used when compared to the use of the term "Difable" which represents people with differently able skills.

\subsection{Indonesia emergency literacy Difable}

Both media soap opera and news portal give an indication of the existence of media in Indonesia leave a strong stigma viewing Difable. Moreover, soap opera and news portal are strategic media in presenting information and entertainment to the audience. The scene of physical harassment and negative views by the environment clearly depicted by the soap opera and merely aired as entertainment is a logical flaw that should not be happened by the media. The use of public frequencies "rented" by Private Televisions bind social responsibility and journalism about the truth. The truth of this case is the identity of the Difable from stigma. Truth is the main thing through content production[9]. Similarly, the news media portal as the media convey the truth should not display the terms that precisely marginalized certain parties without showing a neutral error[10]. Even if there are parties that are proven wrong also not entitled to get bad opinions from journalists. The truth presented by the news portal requires journalists to preach what actually happens according to the facts. Because of the tendency of the news to take a standpoint that actually builds a discriminatory construction to the Difable. 


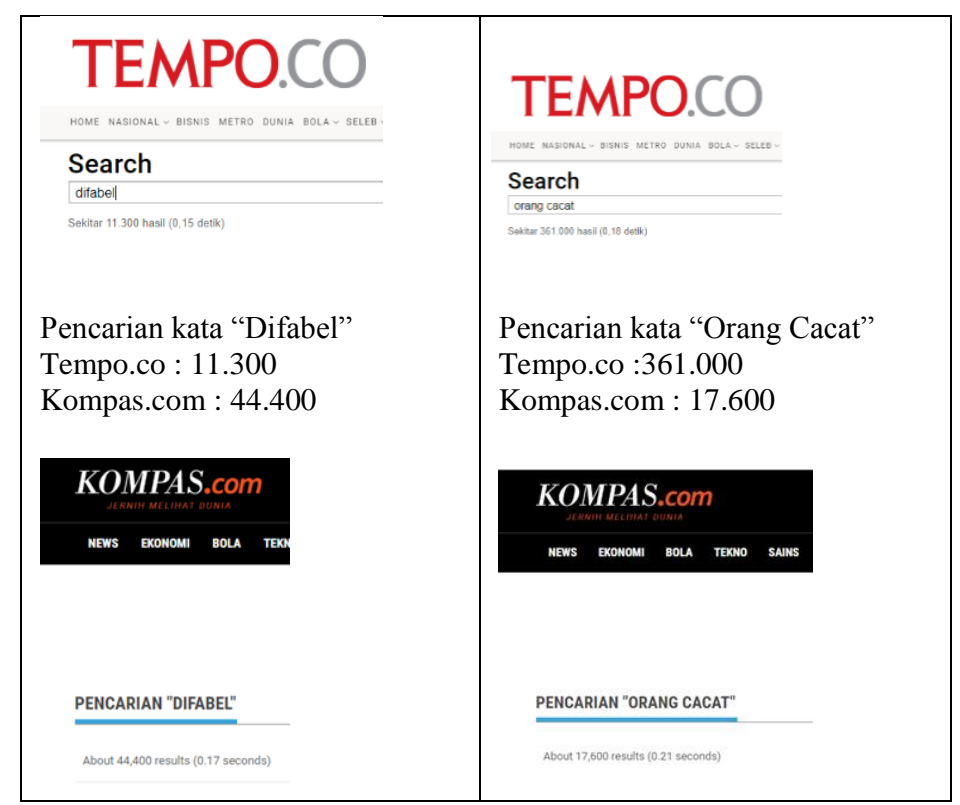

Source: www.kompas.com dan www.tempo.co

Fig. 2. Searching for "Difabel" and "Disabled" on SK Tempo.co and Kompas.com on June $18^{\text {th }}, 2018$

The interview with Ismail, Deaf-Difable SIGAB activist (Sasana Integrasi dan Advokasi Difabel) recounted once interviewed by a local news portal in Yogyakarta. Until then when reading the results of printed news, Ismail was disappointed because what was reported did not represent what he revealed in the interview. Instead, the newspaper tends to dramatize which is too much for him. This has an impact on the media's distrust in reporting on disability issues. Conditions like these often occur in news media, how disability issues are only considered as objects of empathy and pity. The Difable have the same right to be free from the stigma. For Ismail, the media should preach the struggles of the public rights of the Difable. Or by taking the viewpoint of the first person, namely the Difable who have been independent and can indeed be equivalent like the others. But in fact not all news media able to do inclusivity in the newsroom process.

Both televisions and news portals, unleashing stigma about disabilities. By choosing a word without using the term "defect", "child of bad luck" and other negative terms. Likewise with news portals that often do objectification on the issue of Difable. With a viewpoint that put aside the side of self-sufficiency and a positive ability unilaterally on the disability. Lure empathy and sub-marginal perception of the news portal. This stigmatization condition is natural because it is almost minimal in involving Difable in content production. Human resources of media generally are the "normal" people will see the issue of disability as an object, not as a subject and this bias involves the viewpoint of the Difable themselves in the production process[2]. The lack of Difable media crew involvement in the production process influences the media's perspective on disability issues. 


\section{Conclusion}

Media has a role and power in creating representations to audiences. The stigma and stereotypes potentially go as truth while it goes to be repeated continuously by media. The public has no power in defining the issue of disability because of its belief in the media as a transmitter of information. Therefore, the media holds the responsibility in presenting and presenting content that is stigmatized to the public in order, not to marginalize others.

Stigmatization of the Difable and the dominant objectification in news reporting and soap opera programs in Indonesia. This common phenomenon is considered reasonable and prevalent for the public because the media have public confidence in conveying information. Not only that, this ongoing stigma is a violation of the code of Conduct of Law No. 8 of 2016 on the rights of stigma-free for the Difable.

Using representational analysis[1] in disabling construction on news portals and soap opera impressions. How the process of representation occurs through the codes into a mutually agreed conception by the audience. Then describes the concept of inclusiveness and media accessibility. Where inclusiveness is an attitude to give the same perception to each party without discrimination.The ability of the media to be accessible for Difable people with different disabilities (deaf, blind, etc.) as a form of information justice called accessibility to the media.

The case on the soap opera "Ayah, Mengapa Aku Berbeda" and the news portal Tempo.co and Kompas.com are examples of negative Difable representations. Its construct the Difable as empathic and sub-marginal objects. While on the other hand, the Difable as audiences has not become a consideration in the impact of representation caused by these media.

Under these conditions, the media has an opportunity to change the existing stigma. Media has a central agent doing media literacy to the audience[11]. By producing news that does not make the issue of disability an object of empathy and objectification but rather to the fulfillment of its public rights as other non-Difable people. Then the show soap operas that no longer display the Difable characters as objects that hurt and provoked a sense of empathy. But normalize the Difable character as a person in general without making different abilities as objects of physical abuse. The media plays a role in forming neutral disability representations and not marginalizing.

\subsection{Acknowledgements}

Acknowledgments. This research is dedicated to the Faculty of Social and Political Science, University of Gadjah Mada, Yogyakarta. 


\section{References}

[1] S. Hall, Representation: Cultural Representations and Signifying Practices. The Open University: Sage Publication Ltd, 1997.

[2] N. Bendukurthi and U. Raman, "Framing Disability in the Indian News Media: A Political Economy Analysis of Representation," J. Creat. Commun., vol. 11, no. 2, pp. 135-153, 2016.

[3] J. Fiske, Television Culture. London: Routledg, 1997.

[4] R. S. Black and L. Pretes, "Victims and Victors: Representation of Physical Disability on the Silver Screen," Res. Pract. Pers. with Sev. Disabil., vol. 32, no. 1, pp. 66-83, 2007.

[5] Rahayu, Membangun Sistem Komunikasi Indonesia: Terintegrasi, Adaptif dan Demokratis. Yogyakarta: PKMBP, Yayasan TIFA, 2016.

[6] F. Firdaus and F. Iswahyudi, "AKSESIBILITAS DALAM PELAYANAN PUBLIK UNTUK MASYARAKAT DENGAN KEBUTUHAN KHUSUS,” Yogyakarta, 2010.

[7] KPI, "10 Sinetron Ftv bermasalah dan tidak layak ditonton," 2014. [Online]. Available: http://www.kpi.go.id/index.php/id/siaran-pers/32063-kpi-10-sinetron-ftvbermasalah-dan-tidak-layak-ditonton .

[8] Y. Nugroho, D. A. Putri, and S. Laksmi, "Memetakan Lansekap Industri Media Kontemporer di Indonesia," vol. 2, no. 1, pp. 1-89, 2012.

[9] A. Harsono, Agama saya adalah jurnalisme. Yogyakarta: Kanisius, 2010.

[10] B. Azkiya, Marisa, "PESAN PROFETIK KAUM DIFABEL DALAM MEDIA SOSIAL (Analisis Isi Timeline Akun Facebook Mahasiswa Difabel Universitas Islam Negeri Sunan Kalijaga Yogyakarta)," 2015.

[11] Tim Peneliti PKMBP, Model-Model Gerakan Literasi Media dan Pemantauan Media di Indonesia. Yogyakarta: Pusat Kajian Media dan Budaya Populer cooperated with TIFA Foundation, 2013. 